\title{
ADONIRAN BARBOSA E O POGRÉSSIO DE SÃO PAULO
}

\author{
ADONIRAN BARBOSA AND THE SÃO PAULO'S POGRESS
}

Wilson José FLORES JR. ${ }^{28}$

\begin{abstract}
RESUMO: Nos sambas de Adoniran Barbosa, as relações entre causa e consequência aparecem truncadas: uma coisa não leva necessária nem logicamente à outra, apresentando resultados que frustram as expectativas do ouvinte quando não caminham diretamente para o absurdo. A análise detida das letras de algumas de suas composições revela uma linguagem que o tempo todo afirma e nega, diz e desdiz, valorizando no mesmo movimento em que desmerece o que afirma. Esse travamento, além de recurso cômico, liga-se intrinsecamente às vicissitudes do processo histórico do qual emerge, em que o "pogréssio" se realizou, a cada momento, por meio da reprodução de diferentes formas do atraso.
\end{abstract}

PALAVRAS-CHAVE: Música popular brasileira; Modernização; Alteridade; Expressão popular; Dialética.

ABSTRACT: In Adoniran Barbosa's sambas, relations between cause and consequence appear garbled: one thing does not lead logically nor necessary to the other and sentences often meaningless. A detailed analysis of the lyrics to some of his music reveals a language that claims while denying, valuing in the same movement in which discredits what he says. This procedure, besides being a comic procedure, refers to the vicissitudes of the historical process from which emerges, in which the "pogréssio" was made through the reproduction of different forms of the backwardness.

KEYWORDS: Brazilian popular music; Modernization; Alterity; Popular expression; Dialetic.

Adoniran Barbosa é querido e admirado por muitos. Por isso mesmo, as considerações a seu respeito são muitas e, por vezes, bastantes díspares. De expoente máximo do samba paulistano a gênio da cultura popular e outras formas de valorização bem intencionadas e frequentemente paternalistas, até o ingênuo palhaço a repetir sem reflexão certas ideologias do progresso à paulista; sua imagem oscila entre o estereótipo

\footnotetext{
${ }^{28}$ Doutorando (Bolsista CNPq). Programa de Pós-Graduação em Ciência da Literatura. Faculdade de Letras - Universidade Federal do Rio de Janeiro (UFRJ) - Rio de Janeiro - RJ - CEP 21941-917 - Brasil - wfloresji@ufrj.br
} 
do pobre ingênuo, malandro, descompromissado e desinteressado em dinheiro ou poder e a figura do cantor e ator de rádio que, submetido aos ditames da incipiente indústria cultural de São Paulo dos anos 1950, escorregava, às vezes, em soluções facilmente assimiláveis, pouco comprometedoras em relação à ideologia dominante e prontas a agradar a audiência.

Parte dessas imagens aparece claramente num programa "O fino da Bossa", comandado por Elis Regina, do qual Adoniran participou em 1965. Na conversa com o sambista, a cantora demonstra admiração, respeito, mas também uma pontinha de paternalismo: Adoniran é um ótimo músico, mas menor, meio palhaço, distante da erudição de outros compositores admirados pela apresentadora, como Vinícius de Moraes, tanto que, em certo momento da conversa, Elis comenta:

Elis: Adoniran, eu sei, mas muita gente não sabe, você foi parceiro por correspondência de um dos maiores nomes da música brasileira, não só da música moderna, mas da música brasileira mesmo de todos os tempos.

Adoniran: Sim, senhora.

Elis: $\quad$ Agora eu queria saber como foi que aconteceu isso. Como é que você se tornou parceiro de Vinicius de Moraes sem sequer conhecê-lo?

Adoniran: Fácil, é fácil, fácil.

Elis: Mas como?

Adoniran: A Aracy de Almeida, que é muito amiga dele, ele tava em Paris nessa ocasião, na Unesco, e ela recebeu uma carta dele e dentro da carta veio assim essa letra, dois versinhos, e dizia embaixo 'Aracy, faça o que você quiser com esses versos'.

Elis: $\quad$ Então, a Aracy pegou e deu pra você.

Adoniran: Então eu tava pertinho dela, não é? E ela era ligação minha, não é? Ela disse: 'Ô, Adoniran, bota a música aí'.

Elis: Quer dizer que a letra é de Vinicius de Moraes e a melodia é que é sua.

Adoniran: A letra é de Vinicius e a musiquinha é minha.

As respostas de Adoniran sintetizam um procedimento constante em suas composições, declarações e entrevistas: primeiro, reage à pompa com que Elis Regina pergunta como ele havia se tornado parceiro de "um dos maiores nomes da música brasileira de todos os tempos"; depois, retoma o tom apequenado, brincalhão, e declara que, enquanto a "letra é de Vinicius", “a musiquinha” é dele.

Pouco antes, no mesmo programa, Adoniran mencionara o bairro do Bexiga. Elis perguntou o que era o Bexiga e o sambista respondeu que era "o apelido de um 
bairro chamado Bela Vista”. Elis riu e perguntou por que o apelido, ao que Adoniran respondeu também rindo e em tom jocoso: "Num sei porque que é Bexiga. Eu sei, mas pra explicar demora muito. Então é melhor rapidinho e rasteiro". Ou seja, o tempo todo ele parece estar, ao mesmo tempo, brincando e falando sério, fazendo-se meio de bobo e afirmando quem é e o que conhece, revelando um distanciamento crítico, fino e consciente, ainda que fraturado e problemático, que ele expressa e, por assim dizer, representa.

Uma das tentativas de entender esse modo de expressão é um pequeno artigo de José Paulo Paes (1985, p.260-264), chamado "Samba, estereótipos e desforra". Nesse texto, em tom elogioso, Paes afirma que a particularidade de Adoniran como músico e artista foi ter criado um "samba diferencialmente paulista", construído a partir de dois motivos principais: primeiro, pela incorporação da "fala ítalo-caipira" das ruas de São Paulo, a qual Adoniran saberia usar habilidosamente criando "efeitos saborosos"; segundo, e principalmente, pelo fato de seus sambas, "no plano dos valores esteriotípicos", ocuparem-se "em retratar o mundo suburbano do trabalho", ao invés do "mundo marginal da malandragem e da boêmia", que seria comum ao samba carioca.

O crítico, então, identifica nas canções certa ênfase na positividade do trabalho e em sua correlata negação da vadiagem. Destaca também um apego ao "legalismo", uma aceitação ingênua das "leis de propriedade e de trânsito", que marcaria músicas como "Iracema", "Saudosa Maloca", entre outras, e que Paes identifica como um "anseio de dignidade humana" e não como sintoma de uma "consciência alienada em face da ideologia de dominação" (passo difícil esse, revelador da dificuldade que temos no Brasil de analisar criticamente as "produções populares"; uma corda bamba complexa e sensível, que costuma oscilar entre paternalismo condescendente e aborrecimento ilustrado).

Segundo Paes, esse "bom mocismo" (a expressão é minha) de Adoniran seria contrabalançado pela irreverência e pelo humor, que dariam um toque sutil e bem dosado à representação das personagens e das situações, fugindo, em muito, do exotismo e do gosto pelo pitoresco. Com isso, os sambas de Adoniran operariam uma espécie de "desforra histórica, inconsciente talvez e em todo o caso de segunda instância, daquele 'carcamano' que o elitismo dos modernistas de 22 só soube representar com as tintas fáceis da irrisão". Por isso, conclui, "no contraste entre a 
grosseria da paródia semi-erudita assinada com pseudônimo italianado [refere-se a Juó Bananere] e a finura do humor popularesco assinada com pseudônimo abrasileirado, há mais do que uma distância histórica, uma lição em que talvez não seja ocioso meditar".

A análise de José Paulo Paes aponta para certa oscilação entre reproduzir o discurso oficial e manter o distanciamento pela irreverência e pelo humor que, levada às últimas consequências, realmente parece ser uma característica central dos sambas de Adoniran. Marca também um contraponto interessante, embora não desenvolvido, entre a pretensão "semi-erudita" de algumas tentativas modernistas de aproximação com o "popular" e o desprendimento bem-humorado de Adoniran. No entanto, na medida em que não desenvolve as implicações dessas percepções, acaba por fazer uma repreensão equivocada às canções do sambista, pois não há efetivamente um elogio do trabalho e do progresso em Adoniran, ao contrário. A não ser em alguns poucos momentos, em uma ou outra canção em que se percebe uma tentativa meio patética de responder a certa demanda de adequação linguística e ideológica, as canções operam na contracorrente do discurso triunfalista do capitalismo brasileiro e paulistano e da crença cega no progresso. E isso nos anos 1950, quando o desenvolvimento econômico e industrial ainda oferecia uma base para pensar um futuro mais orgânico, integrado e menos desigual para o Brasil.

Outra discussão importante e bastante sugestiva está num pequeno texto de Antonio Candido publicado na capa do LP Adoniran Barbosa, de 1975, e reunido em Textos de intervenção. Com a precisão e a concisão que lhe são habituais, o crítico afirma que o compositor, "lírico e sarcástico, malicioso e logo emocionado", "é um paulista de cerne que exprime a sua terra com a força da imaginação alimentada pelas heranças necessárias de fora". Por isso, discorda que sua linguagem seja uma combinação de italiano e português. Na opinião de Candido, o músico "colheu a flor" da "mistura, que é o sal da nossa terra," e "produziu uma obra radicalmente brasileira, em que as melhores cadências do samba e da canção [...] se aliaram com naturalidade às deformações normais do português brasileiro" para "inventar no plano da arte a permanência de sua cidade e depois fugir, com ela e conosco, para a terra da poesia, ao apito fantasmal do trenzinho perdido da Cantareira" (CANDIDO, 2002, p.211-213).

\section{O "SAMbista de São Paulo"}


Se tomado inteiramente a sério, o consenso de que Adoniran é o sambista de São Paulo aponta não apenas para o fato de seus sambas terem a cidade como cenário e incorporarem o sotaque típico das ruas em sua melodia, mas, principalmente, porque, ao fazer isso de modo intenso e consequente, seus sambas captam um modo de ser que emerge das contradições concretas que formaram (e deformaram) o pogréssio e o desenvolvimento de São Paulo, colocando em cena alguns limites desse processo pela perspectiva dos mais pobres. E mais, ao fazer isso acaba por problematizar a própria dificuldade (ou mesmo impossibilidade) de configuração da perspectiva popular.

A sonoridade própria da fala cotidiana, da linguagem da rua, sempre foi a principal matéria-prima do músico popular. Em grande medida, a música popular se constitui, justamente, a partir da incorporação do jeito particular com que a linguagem expressa os problemas e conflitos corriqueiros. No caso de Adoniran, a incorporação dos diferentes tipos urbanos, do drama cotidiano e miúdo que representavam e da linguagem falada nas ruas de São Paulo define parte importante da imagem que João Rubinato forjou para si como Adoniran Barbosa ${ }^{29}$.

De 1955 a meados dos anos 60, Adoniran atuou como ator num programa humorístico da rádio Record chamado "História das Malocas", que marcou profundamente a identidade que o músico forjou para si. Esse programa, escrito e dirigido por Oswaldo Moles, inspirou-se no grande sucesso que "Saudosa maloca" alcançou em 1955 interpretada pelos Demônios da Garoa. Era povoado por tipos populares que tentavam, das mais diversas formas, sobreviver à miséria e à cidade. Entre eles, destacava-se Charutinho, um “crioulo malandrinho" morador da Favela do Piolho, protagonista do programa e interpretado por Adoniran. Em um dos programas, Charutinho e Terezoca (outra personagem) têm uma conversa sobre a elaboração da letra de samba:

- Me diga uma coisa, Charutinho? O qual que é a receita para fazer uma letra de samba?

\footnotetext{
${ }^{29}$ O nome real do compositor era João Rubinato. Consta que tenha nascido em 1910 (embora ele mesmo dissesse, às vezes, que foi em 1912, mas que preferia 1910 por ser o ano de fundação do Corinthians; $C f$. MUGNAINI Jr., 2002, p.13-14), em Valinhos, na época subúrbio de Campinas, no interior de São Paulo, filho de um casal de imigrantes italianos. Ao começar sua carreira de músico na capital, como afirma Antonio Candido, "adotou o nome de um amigo funcionário do Correio e o sobrenome e um compositor admirado", o que teria sido uma ideia "excelente, porque um artista inventa antes de mais nada a sua própria identidade" (CANDIDO, 2002, p.211).
} 
- $\quad$ Bom, pá escrevê uma boa letra de samba, a gente tem que tê uma condição principal.

- $\quad$ É saber fazer rimas, é?

- $\quad$ Não. Pá escrevê uma boa letra de samba, sentida... humana... a gente tem de sê, em primero lugá nalfabeto. Só se for nalfabeto escreve bem. ${ }^{30}$

A conclusão paradoxal é enunciada em tom de ditado popular: para escrever bem um samba tem de ser, antes de mais nada, analfabeto. $O$ efeito cômico da conclusão inusitada e meio absurda, que subverte as expectativas do ouvinte, é acompanhado por um tom proverbial que confere ao enunciado uma seriedade como que vinda de um conhecimento profundo extraído da experiência. Assim, se é verdade que o inusitado, o absurdo, o paradoxo promovem o riso, é certo também que seu sentido não se esgota no simples desejo de fazer graça, mas condensa, ao mesmo tempo, uma experiência direta, cuja seriedade e validade são reforçadas pelo tom de sentença do ditado popular. Encontra-se novamente aqui o mesmo procedimento construtivo, baseado no convívio estreito e ambivalente do humor (que parece rebaixar a importância do que é dito, como se fosse apenas uma brincadeira) e de certo tom proverbial (fonte da seriedade e da força das afirmações).

Dessa mesma ordem, embora com sentido diferente, consta uma entrevista de Adoniran reproduzida no CD Documento Inédito ${ }^{31}$ (lançado em 1984, dois anos após a morte do compositor), na qual ele diz:

Eu sempre gostei de samba. Eu sou sambista nato. Gosto de samba... não foi fácil pra mim entrar como compositor. Foi difícil porque ninguém queria nada co'as minhas letras, co'as minhas letras que falavam de 'nóis vai', 'nóis qué', 'nóis fumos', 'nóis peguemos'... Agora, precisa saber falar errado. Se não souber falar errado, melhor... não falar errado. Melhor ficá quieto... ganha mais, sabe?

"Precisa saber falar errado"; esta é a formulação do compositor para o que Antonio Candido chamou de "deformações normais do português brasileiro" (CANDIDO, 2002, p.11). A questão é que a compreensão do crítico nunca foi compartilhada por certas ações oficiais de "defesa da língua"; Adoniran não enfrentou apenas dificuldades no início de sua carreira como também foi vítima, durante os anos

\footnotetext{
${ }^{30}$ Faixa do LP História das Malocas. São Paulo, Chantecler, s.d.

${ }^{31}$ Adoniran Barbosa, Documento inédito, Gravadora Eldorado. O trecho citado é a transcrição de trecho de uma das entrevistas reproduzidas no CD.
} 
do "milagre brasileiro" e de ascensão festiva da "Jovem Guarda", de uma censura tácita por parte das rádios, muitas das quais deixaram de tocar suas composições, não apenas porque seu público deixou de solicitá-las, embalado pelos modismos da indústria fonográfica, mas por deliberado boicote; o "velho" Adoniran parecia desafinar do arranjo moderno da nação. Daí, inclusive, o tom mais lamentoso da declaração. Ainda que o enunciado tenha algo de cômico, Adoniran o diz com a maior seriedade e com certo pesar. O efeito de sentido, contudo, é próximo ao anterior: não basta querer imitar, "falar errado" não é uma simples brincadeira ou uma caricatura, é um conhecimento aprendido por meio da experiência direta. Ou seja, o "errado" não é um mero pastiche da língua padrão, mas sim, o modo de falar de um setor da população, sendo, portanto, legítimo ${ }^{32}$.

Ao transformar em canção a oralidade cotidiana, o músico popular acaba por dar forma a dramas, pontos de vista e reivindicações próprios das classes oprimidas, num movimento que, devido a sua intensidade e capacidade de concisão, sintetiza críticas, muitas vezes indiretas, enviesadas, mas que se expressam para além de sua manifestação cotidiana possível. Daí a rua ser o espaço preponderante nas canções. Ao invés do recinto fechado, do quarto, do "cantinho", que dão o tom intimista da Bossa Nova, vemos uma série de flashes de espaços externos e coletivos: a Av. São João de "Iracema", o "Viaduto Santa Efigênia", as festas do "Morro da Casa Verde", o carnaval de "Vila Esperança" etc.

Mesmo as desilusões amorosas não assumem a forma do sofrimento individual, nem o amor surge sublime e transcendental. Ao contrário, os "dramas" são tratados num contexto no qual adquirem feição de exemplos, mais do que de lamentações individuais. "Malvina”, “Apaga o fogo, Mané”, "Não quero entrar", "Pafunça” são algumas canções que expressam bem essa condição. Sem contar "Dor de catuvelo" (de 1959), que ironiza o intimismo a que o título jocosamente se refere.

Os sambas de Adoniran parecem sempre visar a certa exemplaridade, sendo algo como causos musicados, olhando a cidade e seu progresso da perspectiva daqueles que

\footnotetext{
${ }^{32}$ Outro exemplo que vai nessa mesma direção, desta vez extraído do programa "MPB especial”, da Rede Cultura: "Não é dorme, é drome, o certo é drome. E também não degrau, é dregau o certo. Se quiser falar degrau pode, mas o certo é dregau". (programa reproduzido no CD A música brasileira por seus autores e intérpretes: Adoniran Barbosa, produzido pelo SESC São Paulo e pela Fundação Padre Anchieta).
} 
ficaram à margem, na contramão do processo. A esse respeito, veja-se a letra de “Conselho de mulher" (1953):

\author{
(Declamando) \\ 'Quando Deus fez o homem, \\ Quis fazer um vagolino que nunca tinha fome \\ E que tinha no destino \\ Nunca pegá no batente \\ E vivê forgadamente. \\ O homem era feliz \\ Enquanto Deus assim o quis. \\ Mas depois pegou Adão \\ Tirou uma costela e fez a mulher, \\ Desde então o homem trabalha pr'ela. \\ Vai daí home reza todo dia uma oração \\ Se quisé tirá de mim arguma coisa de bão, \\ Que me tire o trabaio, a muié, não!' \\ Pogréssio, pogréssio. \\ Eu sempre escuitei falá \\ Que o pogréssio vem do trabaio, \\ Então amanhã cedo \\ Nóis vai trabaiá... \\ Quanto tempo nóis perdeu na boemia \\ Sambando noite e dia \\ Cortando uma rama sem pará \\ Agora escuitando o conselho da muié \\ Amanhã vou trabaiá \\ Se Deus quisé... \\ (Breque) \\ Mas Deus num qué!
}

No início, a introdução parece caminhar para uma condenação da mulher como responsável pelo fim da vida "forgada" do vagolino e, portanto, pelo início do sofrimento do homem. No entanto, no final, a condenação recai sobre o trabalho, enquanto a mulher é enfaticamente defendida em prece pelo homem. A introdução falada e com ares de parábola, já diz bem a que veio a música.

A música toda é o avesso do elogio da modernização. Usa imagens e lugares comuns relacionados à importância do trabalho e do progresso ("o pogréssio vem do trabaio"; o tempo "perdido" na boemia, sambando noite e dia etc.), mas para subvertêlas. O samba se constrói, mesmo, a partir dessa subversão. A introdução, bem como a pronúncia consciente e jocosamente "errada" de toda a letra, em especial, do 
"pogréssio", além do descaso com a crença de que "o pogréssio vem do trabaio" que ele apenas "escuitou falar" e que o convenceu tão pouco que ele decidiu ir "amanhã cedo" trabalhar, são índices evidentes de inversão do discurso oficial.

Como arremate, há a ironia do breque final: após aparentemente reconhecer que a boemia foi uma perda de tempo, um atraso de vida, diz que, seguindo o conselho da mulher, amanhã ele finalmente vai trabalhar, se Deus quiser. O problema é que "Deus num qué”. Como se vê, a subversão dos sentidos esperados e comuns de certos clichês é procedimento construtivo e, por isso, recorrente.

Como se sabe, no seu sentido corriqueiro, a expressão "Se Deus quiser" visa enfatizar um pedido ou desejo a que se almeja muito ver realizado. Deus, então, é invocado para colaborar numa tarefa que o sujeito reconhece não depender apenas de seu esforço e vontade, pois, no caso, dadas as dificuldades e a penúria em que vive, conseguir um emprego é um desafio que mantém sempre algo de imponderável e arbitrário. No samba, ao contrário, a boa ação "apoiada por Deus" é permanecer sem trabalho fixo e na boemia. A "opção" de vida que parecia estar sendo criticada e colocada em dúvida pela aparente certeza na validade do trabalho e do progresso surge, inesperadamente, como "abençoada", condição reforçada numa das interpretações dos Demônios da Garoa que introduzem outro verso como complemento ao breque final: “Deus é bonzinho pra nóis". O humor e a piada não estão exatamente no inusitado do breque final, mas na construção toda que repete, jocosamente, algumas das ideologias mais difundidas pelo discurso oficial sobre a validade do trabalho, a dignidade do trabalhador e a importância coletiva do progresso, para subvertê-las.

\section{SAMBA E MEMÓRIA: "SAUdOSA MALOCA"}

"Saudosa maloca" (1951) é, provavelmente, a obra-prima de Adoniran e uma das grandes composições da música popular brasileira.

Se o senhor não tá lembrado,

Dá licença de contar

Que aqui onde agora está

Esse edifício alto

Era uma casa velha

Um palacete abandonado.

Foi aqui, Seu moço, 
Que eu, Mato Grosso e o Joca

Construímos nossa maloca.

Mas um dia,

Nóis nem pode se alembrá,

Veio os home co'as ferramenta,

$\mathrm{O}$ dono mandou derrubar.

Peguemos tudo as nossas coisa

E fumos pro meio da rua apreciar a demolição.

Que tristeza que nóis sentia

Cada tauba que caía doía no coração.

Mato Grosso quis gritar, mas em cima eu falei:

Os home tá co'a razão nóis arranja outro lugar.

Só se conformemo quando o Joca falou:

Deus dá o frio conforme o cobertor.

E hoje nóis pega paia

Nas grama do jardim

E para esquecer

Nóis cantemos assim:

Saudosa maloca,

Maloca querida

Din din donde nóis passemo

Dias feliz de nossa vida.

É possível afirmar, com relativa tranquilidade, que o assunto central da canção é a memória. A letra começa com o Eu interrompendo a caminhada apressada e distraída de alguém, aparentemente identificado por ele como pertencente a outra classe social, devido aos tratamentos "senhor" e "Seu moço". Em meio à agitação da vida na cidade e à mistura de falta de tempo, correria, cansaço e ausência de pontos de referência urbanos relativamente estáveis para a fixação da memória, o homem sequer percebe a paisagem ao seu redor, a despeito (ou pelo fato mesmo) de ela ser transformada rápida, constante e violentamente. $\mathrm{O}$ excesso de estímulo e o fato de que nada dura o suficiente para tornar-se referência parecem explicar o comportamento desatento e blasé. A canção começa interrompendo esse fluxo violento e aparentemente inexorável, chamando a atenção do passante para um detalhe quase insignificante das transformações urbanas de São Paulo: o edifício alto, símbolo de modernização e riqueza, mas índice também da especulação imobiliária e do acúmulo selvagem de capital, torna-se algo vivo, deixando de ser apenas uma construção, um valor monetário, um dado, uma estatística. Ocupa o lugar que um dia foi habitado por pessoas que ali 
começaram a construir uma vida; foi referência de esperança de uma vida mais digna e melhor para três "desclassificados". Em meio ao caos imposto pelo capital, um flash, um momento de rememoração que traz não a imagem ideológica da "locomotiva do Brasil", mas da cidade habitada por pessoas, dos espaços cotidianos de sociabilidade, onde se desenrolava a vida de todo dia.

Em seguida, mais uma vez, instaura-se a violência e a arbitrariedade, tão comuns nas letras de Adoniran porque corriqueiras na vida dos mais pobres. Os homens com as ferramentas e a ordem do dono surgem como uma espécie de "força do destino", inegociável, incompreensível, inacessível, irresistível. Não há forma de se proteger, não há mediação institucionalizada para o conflito. Mandam o dinheiro e a força bruta, sem que se vislumbrem minimamente as estruturas do Estado de Direito.

A seguir, o drama dos três amigos, embora pungente, é apresentado de forma um tanto patética e aparentemente conformada, o que, por um lado, ajuda a acalmar as consciências paternalistas, uma vez que o sentimentalismo da letra alia-se com o conformismo das classes mais abastadas e com seu desinteresse pelo destino coletivo, ao mesmo tempo em que alimenta certa "compaixão" vazia por parte das "boas consciências". Mas, por outro lado, o jogo entre a expressão óbvia da violência e seu tratamento sentimental, mais uma vez, opera de modo truncado a difícil dialética da expressão popular possível em uma sociedade sem alteridade, para a qual a figura do pobre só faz sentido se enquadrada na figura do "bom, ingênuo e coitado" ou na do “feio, sujo e malvado". Movimento difícil, mas que não elimina as sutilezas da crítica, assim como não se pode negar seu truncamento e seu flerte com o sentimentalismo. Se um desmerece o outro, também ambos se relativizam e, se não vemos a configuração política do conflito, é justamente porque falta a base social e histórica para que ela se efetivasse; no contexto da canção, se o conflito assumisse feição política, pareceria inverossímil e forçado, quebrando a leveza e a força da composição que possui a força e a recorrência obsessiva do trauma: dos amigos que nunca deixam de lembrar o acontecimento, da cidade indiferente à memória e ao passado. O samba que é quase um hino de São Paulo é carregado de negatividade.

No final, o paradoxo (“e pra esquecer nóis cantemos assim”), em certa medida apenas aparente, parece configurar a memória como forma de resistência à devastação contínua promovida pelo progresso da cidade. Para esquecer a penúria que caracteriza o 
tempo presente ("e hoje nóis pega paia, nas grama do jardim”), bem como a violência e arbitrariedade do despejo, lembram dias felizes em que acreditavam viver com certa dignidade num lugar que identificavam como uma casa, um lar. A memória, na canção, resiste também ao desaparecimento, à destruição e à reconstrução contínuos de setores inteiros da cidade, os quais alteram sem remissão as poucas referências geográficas e parcos espaços tradicionais (se é que essa palavra possui algum significado em São Paulo) de sociabilidade. Um espaço urbano destituído de sua condição de espaço público, reduzido a tábula rasa, a terra arrasada, sem história ou limites, a serviço quase exclusivo dos interesses privados, da especulação imobiliária e da acumulação de capital. "Saudosa maloca" é como um réquiem ao desaparecimento de laços e tipos de sociabilidade dos quais, hoje, talvez não restem nem sombras.

\section{Abrigo de VAGabundo}

"Abrigo de vagabundo" (1959) retoma as personagens e situações da canção anterior e foi tomado por muitos como o principal exemplo de uma suposta adesão à ideologia do trabalho em Adoniran. Como se procurará discutir, se considerado em sua intrincada construção, o samba revela uma crítica dessa mesma ideologia a que ele, em certa medida, adere de modo torto. Vamos à letra:

Eu arranjei o meu dinheiro

Trabalhando o ano inteiro

Numa cerâmica

Fabricando pote.

E lá no alto da Mooca

Eu comprei um lindo lote

Dez de frente, dez de fundo

Construí minha maloca.

Me disseram que sem planta

Não se pode construir

Mas quem trabalha

Tudo pode conseguir.

João Saracura,

Qu'é fiscal da prefeitura

Foi um grande amigo

Arranjou tudo pra mim...

Por onde andará

Joca e Mato Grosso

Aqueles dois amigo 
Que não quis me acompanhá

Andarão jogados

Na avenida São João

Ou vendo o sol quadrado

$\mathrm{Na}$ detenção.

Minha maloca a mais linda qu'eu já vi

Hoje está legalizada

Ninguém pode demolir.

Minha maloca a mais linda deste mundo

Ofereço aos vagabundos

Que não tem onde dormir.

Inicialmente, pode-se perceber que, ao contrário da maioria dos sambas de Adoniran, "Abrigo de vagabundo" apresenta um tom sério e sentido, que expressa uma conquista (a tão sonhada maloca) como quem lamenta algo. Não há humor, mas uma profunda consternação. A princípio, a letra parece aderir imediatamente ao discurso oficial, fazendo uma espécie de elogio do trabalho como o meio honesto e legítimo de se alcançar uma vida mais digna: depois de um ano inteiro de trabalho pesado, o sujeito abandonou sua vida errante, conseguindo, finalmente, sua maloca. Além disso, sua casa agora está legalizada e, portanto, não mais sujeita ao risco da demolição que, já uma vez, deixou os três amigos sem moradia, "cantando paia nas grama do jardim”. A preocupação com Mato Grosso e Joca, que "não quis" acompanhá-lo, parece revelar também uma mudança de perspectiva, apontando para uma espécie de "conversão" do eu-lírico à "religião" do trabalho. Os amigos que não seguiram o mesmo caminho e continuaram na boemia, devem estar presos ou jogados em uma sarjeta qualquer da, à época, emblemática Avenida São João. Aparentemente, a mensagem da música caminharia para a representação do trabalho como solução para as dificuldades e incertezas da vida dos mais pobres, os quais, se insistissem em permanecer na boemia, só encontrariam desolação e miséria.

No entanto, já no início, a ênfase no ano inteiro de trabalho, fabricando pote numa cerâmica, para conseguir o dinheiro necessário para erguer uma maloca num lugar distante ("lá no alto da Mooca") reforça as dificuldades, a baixa remuneração e a exploração. Mais adiante, percebe-se que não é o direito, advindo do trabalho, que garante a legalização da maloca, como faz pensar os versos: "me disseram que sem planta não se pode construir/ mas quem trabalha tudo pode conseguir", pois o verso 
seguinte desdiz os anteriores, revelando a lógica do privilégio e do favor: "João Saracura, qu'é fiscal da prefeitura / foi um grande amigo / arranjou tudo pra mim". A única menção ao poder público surge sob o suspeitíssimo "arranjou tudo pra mim", que "legaliza" uma construção que, talvez, não devesse ser legalizada (fato que as tragédias anuais em São Paulo, no Rio de Janeiro e em outros lugares do país só fazem acentuar, pois, de forma geral, as mortes ligam-se a ocupações irregulares, muitas vezes "legalizadas" de modo torto: continuam irregulares, mas o poder público, além de fazer vista grossa, instala serviços, escolas, postos de saúde). Ou seja, indiretamente, os versos apontam também para a precariedade da construção, realizada sem planta e absolutamente entregue aos esforços e possibilidades do sujeito, o que demonstra, consequentemente, a ausência de planejamento e de políticas públicas voltadas à habitação e à cidade como espaço de convivência coletivo; longe disso, o que se vê é um "salve-se quem puder", uma terrível "terra de ninguém".

Pode-se afirmar, portanto, que a penúria a que o sujeito está submetido apresenta-se em dois planos complementares: por um lado, a penúria financeira de alguém que mal tem o necessário para começar uma construção e que está condenado a nunca estar plenamente dentro da lei, pois não tem recursos para adquirir uma planta nem para tocar a construção de acordo com o planejado se essa planta pudesse, porventura, ser adquirida. Por outro lado, e principalmente, a penúria de direitos, pois, além de precisar se virar sozinho, sem qualquer respaldo público que assegurasse seu direito à moradia, sua maloca continuaria ilegal não fosse a intervenção suspeita e "salvadora" de João Saracura.

Dessa forma, uma vez que a legalização da maloca só pôde ser conseguida por intermédio do favor, o efeito dos versos "minha maloca, a mais linda qu'eu já vi/ hoje está legalizada/ ninguém pode demolir", se apontam para algum elogio da legalização (o que não se pode negar de todo, dada a cisão profunda que marca todas as relações e a própria consciência do sujeito), ao mesmo tempo evidencia a arbitrariedade como constitutiva dessa mesma "legalização", bem como a violência, tão temida, do despejo e da demolição do pouco que se conseguiu construir com muito esforço.

A preocupação com os amigos Joca e Mato Grosso e o oferecimento da maloca aos "vagabundos que não tem onde dormir", demonstra solidariedade, certa ingenuidade e mesmo certa concessão ao discurso oficial, mas, em sua ambivalência dolorida, revela 
também a particularidade e a exceção da conquista, uma vez que a maloca não será conseguida por todos os que dela necessitam, nem por todos os que trabalham por ela, pois os critérios para compra e legalização não estão postos no campo do direito, da garantia comum, imparcial e universal, mas, sim, no campo das relações pessoais, do compadrio, do favorecimento, da corrupção, e, portanto, do particular, do arbitrário, do instável, do precário e do imponderável. Daí, inclusive, o tom sentido e lamentoso da música.

Assim, mesmo no samba que mais se aproxima do elogio do trabalho como modelo ideal de comportamento para o pobre, percebe-se todo um jogo intrincado na construção da letra que, em suas ambiguidades e ambivalências, revela uma série de explorações a que o trabalhador está submetido, bem como o fato de que o trabalho, em si mesmo, não é garantia de nada: nem de dignidade, nem de segurança, nem de reconhecimento de direitos. O pretenso samba do "elogio do trabalho" carrega em si o seu contrário, expressando, para além de sua cindida adesão, uma crítica e uma negação do discurso oficial.

Outro aspecto importante e que aponta nessa mesma direção é o fato de, nos sambas de Adoniran, os símbolos de modernidade aparecerem sempre pelo avesso da conotação que assumiam no discurso oficial. O automóvel, longe de ser um símbolo de status social, atropela e mata ("Iracema" e "Tiro ao Álvaro"); o "edifício arto", ao invés de símbolo de desenvolvimento, traz, em sua construção, a marca do despejo, da exploração, da arbitrariedade e da violência ("Saudosa maloca"; "Despejo na favela"). Ou ainda, o Viaduto Santa Efigênia (um dos símbolos da modernização da cidade na época) que para Adoniran: "dizem que vai ficá tão bonito esse viaduto que eu acho que

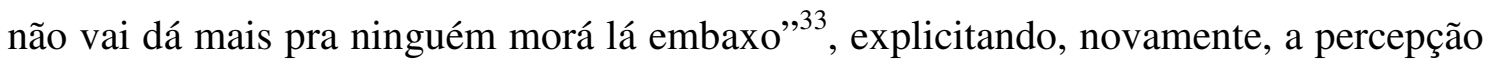
de que o progresso em São Paulo, realiza-se por meio da permanente reprodução moderna do atraso ${ }^{34}$.

\section{SILÊNCIO E EXPRESSÃO}

Adesão e conteúdo crítico. O truncamento, a confusão, a fala intrincada e dissimulada que não diz diretamente e exige decifração vão encontrar no humor uma de

\footnotetext{
${ }^{33}$ Adoniran Barbosa, Documento Inédito, final da faixa 5, "Viaduto Santa Efigênia".

${ }^{34}$ Cf. SCHWARZ, Roberto. Ao vencedor as batatas; ARANTES, Paulo. O sentimento da dialética na experiência intelectual brasileira; e BUENO, André. Memórias do futuro.
} 
suas principais formas de expressão, como já foi sugerido. Para desenvolver melhor esse aspecto, vejamos "Véspera de Natal" (gravada em 1974):

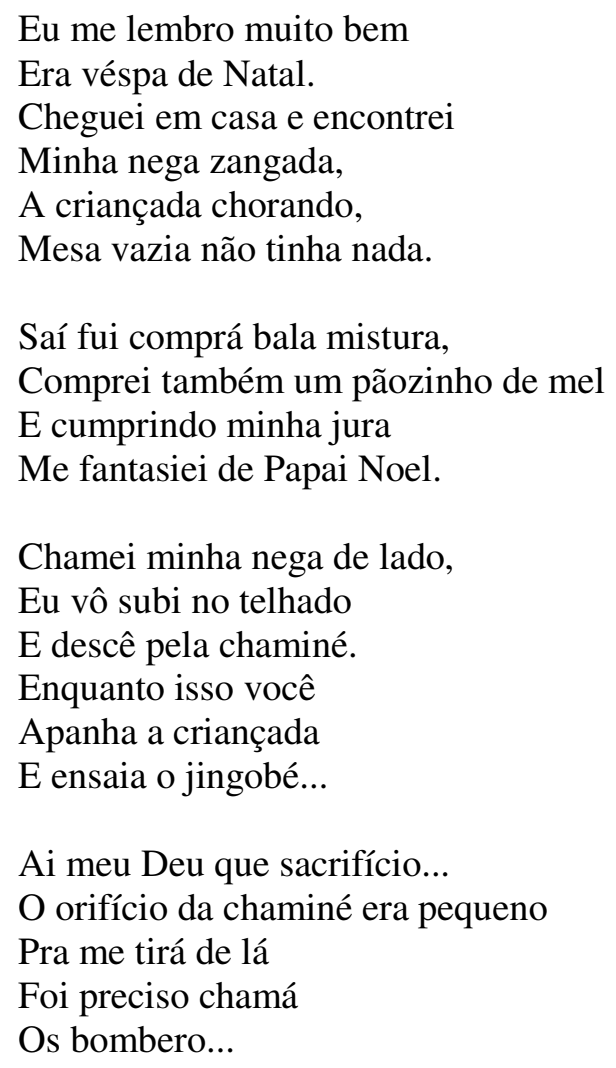

Adoniran diz que compôs Véspera de Natal durante uma festa entre amigos, na qual foi combinado de cada um fazer alguma coisa. Ele fez o samba, sobre o qual dá o seguinte depoimento: "o cara que tiver a grana e fizer uma fita com essa letra... É uma música, é um filme chaplinino. Num tem... ninguém... vou te contar... é linda, tudo" ${ }^{\text {"35 }}$. E diz isso meio rindo, brincando.

A música toda tem algo de piada, tanto que o resultado do final desajeitado e frustrante não é a comoção ou o choro, mas o riso, a despeito da história contada ser, do início ao fim, marcada pela penúria e pelo fracasso. Por isso, analisando o humor expresso nessa canção, percebe-se que ele opera um movimento paradoxal próximo àqueles discutidos anteriormente. Por um lado, o humor diminui a intensidade da denúncia, tornando a "desgraça" descrita, digamos, mais palatável, como que sugerindo algo despretensioso que quer apenas descontrair e divertir. Por outro lado, o ridículo da

\footnotetext{
${ }^{35} \mathrm{Cd}$ Documento Inédito, Eldorado, 1984.
} 
cena do pobre Papai Noel bem intencionado, que queria dar um Natal um pouco mais animado e menos miserável para seus familiares, decreta a impossibilidade de superação, ainda que simbólica, da miséria. Deu tudo errado: o desejo e o empenho em transformar a situação de penúria acabam ridicularizados. O "orifício" da improvável chaminé era pequeno demais e frustrou os sonhos do pobre Papai Noel por absoluta falta de espaço para sua "manifestação", de forma que a penúria da véspera de Natal da família é consumada pela chaminé estreita.

O humor, assim, opera uma espécie de dissimulação, faz graça no mesmo movimento em que denuncia a miséria. Por assim dizer, bota a boca no mundo como se estivesse apenas contando uma piada. Novamente, a expressão não é direta, mas truncada e contraditória, exigindo sempre uma decifração. Veja-se, agora, "Iracema" (composta em 1956):

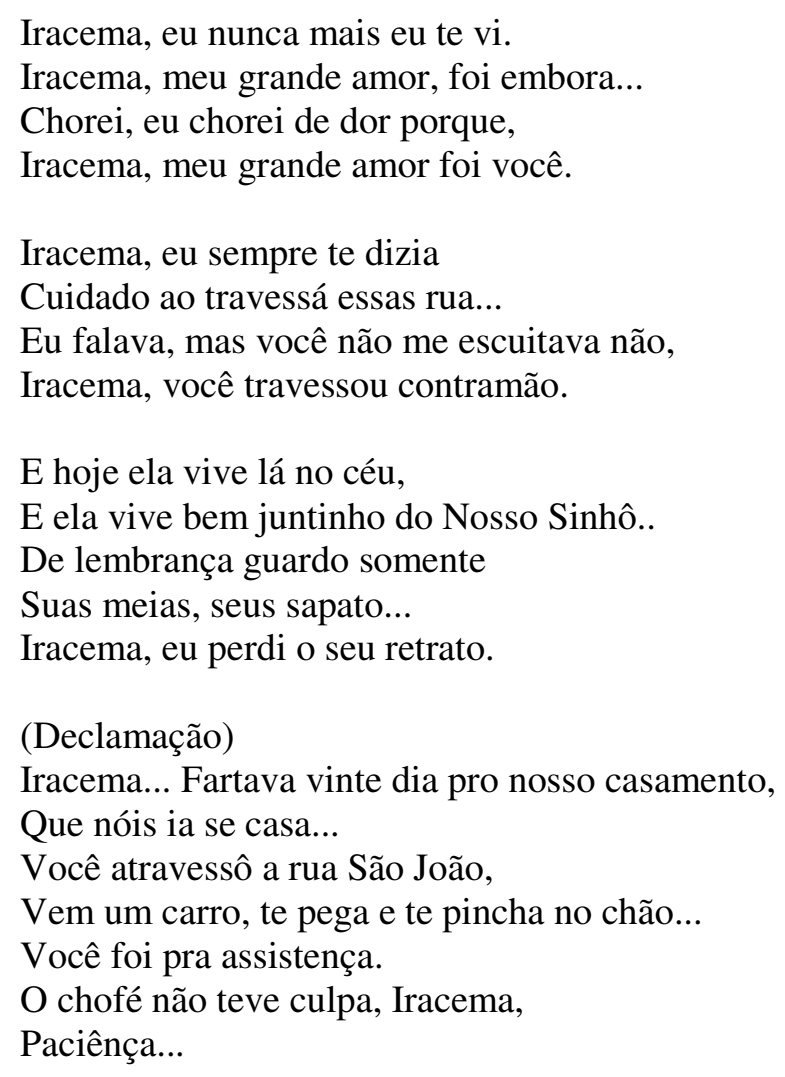

O samba encena muitas questões, a começar pelo atropelamento de Iracema na contramão da São João, avenida que, na época, era um dos grandes símbolos da modernidade paulistana. Ela morre, ou melhor, é morta por não estar na direção determinada pelo "pogréssio". No entanto, o interesse aqui é mais específico: discutir a 
diferença entre duas diferentes interpretações dessa canção, uma dos Demônios da Garoa e outra de Clara Nunes.

As interpretações que os Demônios da Garoa fizeram dos sambas de Adoniran chegaram a ser criticadas porque enfatizariam demasiadamente o humor, perdendo a dimensão trágica das canções e, com ela, seu potencial de denúncia. Em alguns casos, é mesmo possível concordar que haja algo caricato e excessivo, mas, no geral, os Demônios parecem conseguir um bom equilíbrio entre as duas dimensões. Em "Iracema", temos um exemplo desse equilíbrio: o ritmo agitado do sambinha contrasta com o trágico atropelamento de Iracema a vinte dias de seu casamento.

Na interpretação de Clara Nunes, ao contrário, esse contraste desaparece, o ritmo se torna lento, sofrido e dramático, restando apenas o trágico atropelamento. No entanto, observando com atenção, verifica-se que a letra possui, ela mesma, certa leveza, pois fala de uma "tragédia", mas de um modo relativamente ameno, aparentemente conformado, de modo a afirmar e dissimular a intensidade do acontecimento, de modo que, em "Iracema", a ênfase repetida no conformismo também tem como efeito o seu contrário, pois, ao reforçar a "paciença...", o que fica em evidência é justamente a violência do acontecimento. É nesse jogo intricado e oscilante que a força da canção se faz. Por isso, ao enfatizar o sofrimento, eliminando a oscilação entre ritmo e acontecimento, entre conformismo e afirmação crítica, a interpretação intimista de Clara Nunes acaba diminuindo a intensidade da denúncia que, a princípio, gostaria de frisar. O resultado é que, por mais bonitas e bem intencionadas que sejam, interpretações desse tipo para as canções de Adoniran Barbosa sempre têm algo de chato e de pouco convincente, uma vez elas, em geral, sua conotação proverbial lhes conferem um caráter de exemplo; os sambas contam causos.

Assim, nos sambas de Adoniran, as relações entre causa e consequência aparecem sempre truncadas: uma coisa não leva necessária nem logicamente à outra, as causas apresentadas não levam à consequência esperada. Tudo aparece travado, apresentando resultados que frustram as expectativas quando não caminham diretamente para o absurdo, para o non-sense, para sentenças meio sem pé nem cabeça, 
configuradas por uma linguagem que o tempo todo afirma e nega, diz e desdiz, valorizando no mesmo movimento que desmerece o que diz.

Esse travamento, além de recurso cômico, liga-se intrinsecamente às vicissitudes do processo histórico do qual emerge, em que o "pogréssio" se realizou, ele mesmo, de forma truncada, reproduzindo incessantemente e de diferentes modos aspectos do atraso colonial.

$\mathrm{Na}$ ausência de instituições mediadoras que garantissem a expressão política, a percepção crítica popular muitas vezes se ressentiu da falta de condições concretas mínimas para sua expressão efetiva. Frente à inexistência do reconhecimento da alteridade no espaço social que, sem isso, também nunca chegou a se configurar como espaço público, a expressão popular acabou tomando a forma de um discurso dissimulado de aparência conformista, o qual se constrói, justamente, sobre a impossibilidade de síntese, de uma expressão direta e sem volteios que levasse à configuração pública dos conflitos e estabelecesse uma demanda política efetiva de direitos. Ou seja, na medida em que sempre lhe faltou a articulação indispensável à acumulação da experiência, o próprio ponto de vista popular nunca chegou a se configurar plenamente. Daí sua expressão, frequentemente, ser indireta, escorregadia e de difícil apreensão, além de fraturada, cindida e ambivalente.

$\mathrm{O}$ absurdo, o truncamento, os procedimentos intrincados que exigem decifração, tão presentes nos sambas de Adoniran, ligam-se à ambivalência constitutiva da perspectiva popular a que os sambas intrinsecamente se vinculam e da qual são uma expressão. E essa ligação é tão profunda e fundamental que, como vimos, quando um cantor interpreta uma canção concentrando-se em apenas um dos polos da oscilação, numa tentativa de constituir plenamente o ponto de vista, o efeito é inverso, uma vez que a canção tende a perder a força original, tornando-se pouco convincente. Dessa forma, ambiguidade, oscilação, dissimulação parecem configurar a forma possível da expressão crítica popular em meio ao "pogréssio", captada e transformada em música por Adoniran. Sem que, por isso, o compositor se visse ou aceitasse ser visto como um "porta-voz da periferia”, tão ao contrário do que outros tantos costumam fazer. Veja-se um trecho de uma entrevista que faz parte do CD Documento inédito: 
Entrevistador: Você que faz muita música falando de trem, Trem das onze etc., o que que você acha desses tumultos que ocorrem quando quebra algum trem?

Adoniran: Eu num sei porque eu nunca... ói, eu num sei porque eu vou te contar pra você uma coisa: nunca viajei de metrô. Uma vez só viajei de metrô pela Manchete. Eu e o Adalto, Adaulio, presidente do sindicato. Uma vez só viajei com ele pra tirá fotografia... nunca viajei de metrô, num sei nada de metrô. Tenho medo de metrô porque a porta fecha depressa, tenho medo de entrar... a porta fecha depressa, se ocê num é esperto, cê fica pra trás... então, num quero metrô, num quero metrô, num sei nada de metrô.

Entrevistador (rindo e um pouco irritado): Mas a pergunta era de trem, Adoniran. Que servia para você falar do trem das onze, do trem que atrasou...

Adoniran: Metrô é trem. Num quero sabê de metrô.

Ele se recusa a tomar a palavra e fazer a crítica fácil e vazia dos problemas e da dificuldade da vida nos bairros pobres. Não é porta-voz de nada, nem quer ser. A realidade é conhecida, não é necessário repetir o óbvio, a não ser que estivesse interessado em agradar a plateia civilizada (que se horroriza com depredações) ou ao poder público. Não era o caso. E, se fosse, seria uma lamentável ilusão. Adoniran parecia não ter muitas ilusões a respeito de quanto os "poderosos" poderiam ou desejariam "ajudá-lo".

E, mesmo assim, suas canções foram assimiladas de modo ameno, sendo repetidas em eventos oficiais ou na televisão como representações de São Paulo que alegram e apascentam a consciência de muitos paulistanos, em especial no último ano que marcou o centenário do nascimento do compositor. Mas qual São Paulo os sambas representariam? No vazio contemporâneo em que a cidade se perde, sem identidade ou identificação possível, resta falar abstratamente em traços paulistanos, entre os quais Adoniran Barbosa é sempre mencionado. Afinal, para sustentar abstrações bastam ideias, clichês e ladainhas que, de tanto se repetirem, naturalizam-se, a despeito de possuírem maior ou menor grau de vinculação com a realidade material e histórica.

\section{REFERÊNCIAS}


ARANTES, P. E. Sentimento da dialética na experiência intelectual brasileira: dialética e dualidade segundo Antonio Candido e Roberto Schwarz. Rio de Janeiro: Paz e Terra, 1992.

BUENO, A. Memórias do futuro. Rio de Janeiro: 7Letras, 2009.

CANDIDO, A. Textos de intervenção. São Paulo: Duas Cidades; Editora 34, 2002. p.211-213.

MUGNAINI JR., A. Adoniran, dá licença de contar... São Paulo: Editora 34, 2002.

PAES, J. P. Gregos e baianos: ensaios. São Paulo: Brasiliense, 1985. p.260-264.

SCHWARZ, R. Ao vencedor as batatas: forma literária e processo social nos inícios do romance brasileiro. 5.ed. São Paulo: Duas Cidades/Editora 34, 2000.

\section{REFERÊNCIAS FONOGRÁFICAS}

BARBOSA, A.; MOLES, O. História das Malocas. São Paulo: Chantecler, s.d.

BARBOSA, A. Documento inédito. São Paulo: Gravadora Eldorado, 1999.

A música brasileira por seus autores e intérpretes: Adoniran Barbosa. São Paulo: SESC/Fundação Padre Anchieta, 2002.

Artigo recebido em 21/04/2011

Aceito para publicação em 02/08/2011 